\title{
Trophic history of French sub-Alpine lakes over the last $\sim 150$ years: phosphorus reconstruction and assessment of taphonomic biases
}

\author{
Vincent BERTHON,${ }^{1 *}$ Aldo MARCHETTO,${ }^{2}$ Frédéric RIMET, ${ }^{1}$ Emmanuelle DORMIA, ${ }^{1}$ Jean-Philippe JENNY, ${ }^{3}$ \\ Cécile PIGNOL, ${ }^{3}$ Marie-Elodie PERGA ${ }^{1}$ \\ ${ }^{1}$ INRA, UMR 0042 CARRTEL, 74203 Thonon-les-Bains, France; ${ }^{2}$ CNR-ISE, Largo Tonolli 50, 28922 Verbania Pallanza, Italy; \\ ${ }^{3}$ University of Savoie, UMR 5204 EDYTEM, 73376 Le Bourget du Lac, France \\ *Corresponding author: vincentberthon@me.com
}

\begin{abstract}
Like many lakes worldwide, French sub-Alpine lakes (lakes Annecy, Bourget and Geneva) have suffered from eutrophication in the mid-20 th century. Although restoration measures have been undertaken and resulted in significant reductions in nutrient inputs and concentrations over the last 30 years in all three lakes, the limnological monitoring does not extend back far enough to establish the reference conditions, as defined by the European Water Framework Directive. The over-arching aim of this work was to reconstruct, using a palaeolimnological approach, the pre-eutrophication levels and subsequent temporal changes in the lakes trophic status over the last century. The objectives were three-fold: i) to test whether fossil diatoms archived in deep sediment cores adequately reflect past changes in the planktonic diatom communities for these deep sub-Alpine lakes based on data from lake Geneva; ii) to investigate changes in the diatom communities over the last 150 years in the three lakes; and iii) to infer the past total phosphorus (TP) concentrations of the lakes from a diatom based transfer function. Annual palaeolimnological and limnological diatom countings for lake Geneva were strongly correlated over the last 30 years. Most notable differences essentially resulted from both taphonomic and depositional biases, as evidenced by the underestimation of thin skeleton species such as Asterionella formosa and Diatoma tenuis in the palaeolimnological dataset and the presence of many benthic taxa. The fossil diatom records revealed shifts in the communities in the three lakes over time, most of which were changes typically associated with nutrient enrichment. Indeed, in all three lakes, the proportion of Cyclotella spp. was very high before the 1950s, but these species were then replaced by more eutrophic taxa, such as Stephanodiscus spp, by the mid-20th century. From the 1980s, some but not all diatom species typical of re-oligotrophicated conditions (i.e. Cyclotella sp.) re-appeared in all three lakes. Yet, not all changes that occurred in the diatom communities since then may be attributed to decreasing TP. Total phosphorus concentrations inferred from weighted averaging with classical deshrinking in lake Annecy and lake Geneva and weighted averaging with inverse deshrinking in lake Bourget were very close to the monitored values. Comparisons of diatom-inferred TP concentrations to other palaeo-proxies for trophic status revealed though that the transfer functions were rather insensitive to changes occurring below $10 \mu \mathrm{g} \mathrm{L} \mathrm{L}^{-1}$, which limits the study ability to set accurate TP reference conditions below this threshold. However, current diatom community compositions arestill rather different from the pre-eutrophication ones, suggesting that reference conditions are still not achieved.
\end{abstract}

Key words: diatoms, valves preservation, trophic state.

Received: December 2012. Accepted: March 2013.

\section{INTRODUCTION}

The European Water Framework Directive (WFD) (European Commission, 2000) has highlighted a crucial need for the ecological assessment of lakes. One of the key issues faced by managers concerns the establishment of reference conditions, defined by the WFD as those associated with no, or only very minor, anthropogenic impact (European Commission, 2003). These baselines are required to evaluate how much the lake under consideration has been impacted by human activities and to set the restoration objectives. The combination of spatial surveys, modelling, expert judgement and temporally based methods using historical data or palaeo-reconstruction has successfully resulted into the establishment of reference conditions that are specific to some lake ty- pologies (Wolfram et al., 2009). There are however some lakes that lack typologic analogs or for which the type-specific definition of reference conditions may not be accurate enough to assess ecological status. This is particularly true for the very large, deep European lakes, which have unique system dynamics due to their size (Loga et al., 2004). For these lakes, reference conditions need to be site-specific, and, in the absence of sufficiently long-term monitoring data, ecological and chemical reference conditions and deviation from the reference state may be defined through palaeoecological approaches (Bennion and Battarbee, 2007).

This study focused on three French deep sub-Alpine lakes (lakes Geneva, Annecy and Bourget) that are essential elements of social and economic activities in this re- 
gion. All three lakes exhibited some symptoms of eutrophication in the mid-1970s (Anneville, 2002; Millet et al., 2010; Perga et al., 2010). Total phosphorus (TP) concentrations measured during water mixing, either routinely such as for lake Geneva or sporadically as for the two other lakes in the 1970s, confirmed that lakes Geneva and Bourget had reached a eutrophic status (with respectively 90 and $120 \mu \mathrm{g} \mathrm{L}^{-1}$ ), while lake Annecy got, at most, oligo-mesotrophic $\left(17 \mu \mathrm{g} \mathrm{L}^{-1}\right)$ (INRA long-term observatory database). Phosphorus (P) abatement measures were subsequently successfully undertaken, leading to substantial decrease in $\mathrm{P}$ concentrations in the water column over the last 30 years. The lakes Geneva and Bourget are currently mesotrophic with winter $\mathrm{TP}<20 \mu \mathrm{g} \mathrm{L}^{-1}$ while lake Annecy is oligotrophic ( $\mathrm{TP}=6 \mu \mathrm{g} \mathrm{L}^{-1}$, INRA long-term observatory database). Although all lakes are now under routine monitoring (started in 1957 for lake Geneva, 2004 for lake Bourget and 1996 for lake Annecy), these datasets do not extend back far enough to establish lake reference conditions. Previous palaeolimnological studies investigated the ecological changes these lakes have undergone over the last century (Alric, 2012; Druart and Pelletier, 1998; Giguet-Covex et al., 2010; Jenny et al., 2013; Perga et al., 2010) and triggered by changes in nutrient concentrations. None of them though was specifically focussed on reconstructing past TP concentrations.

This study aimed to use an existing diatom based transfer function to estimate the past TP concentration of the three French sub-Alpine lakes, in an approach similar to that of Marchetto et al. (2004) on lake Maggiore. Some transfer functions are now subjected to some strong criticism. In Telford and Birks (2009), different issues are raised: a good replication can be difficult to achieve, the statistical significance must be well adapted to the potential variation of the reconstruct parameter in the studied time period. Juggins et al. (2013) mentioned also different bias of epilimnetic TP reconstruction using diatoms: i) the impact of secondary variables such as alkalinity and depth; ii) the not significant relationship between TP concentration and many taxa in models; iii) the poor or no spatial replicability. Nevertheless, transfer functions remain a good tool to estimate TP concentration using diatom communities, and Diatom Inferred TP concentration can be compared to currently monitored $\mathrm{TP}$ concentration in order to evaluate reference conditions. In a prior step, we tested if the diatom fossil communities archived in the sediment mirrored adequately the changes in the pelagic diatom communities of the lakes over time. There have been, so far, only a handful of such attempts on sub-Alpine lakes. Bennion et al. (1995) and Wessels et al. (1999) performed comparisons based on long-term datasets for the lakes Mondsee and Constance, respectively, and Marchetto and Musazzi (2001) conducted a comparative study on lake Maggiore using the relative abundance of six selected planktonic species. The lake Geneva provided a unique opportunity to conduct such a calibration analysis since i) long-term limnological data, covering the last 30 years, were available, and ii) its annually laminated sediment could be dated at very high-resolution.

\section{METHODS}

\section{Study sites}

The lakes Geneva, Bourget and Annecy are all warmmonomictic lakes located on the northwest edge of the French Alps. The surface water of these lakes is never frozen over. They are the largest deep lakes in France with surface areas of 582, 42 and $27 \mathrm{~km}^{2}$ and maximum depths of 309, 145 and $69 \mathrm{~m}$ for lake Geneva, Bourget and Annecy, respectively.

The increasing anthropogenic pressure due to the demographic and economical development, during the 1930 s and 1940s, led to the first symptom of eutrophication of all three lakes, as evidenced, from palaeo-approaches, by increased Daphnia abundance (Alric 2012), increased organic matter and P content of sediment (Jenny et al., in press; Perga et al., 2010). Maximum levels of eutrophication yet varied between lakes. P abatement measures were undertaken rather early in lake Annecy, through the set up of wastewater collector all around the lake as soon as 1967. As a result, lake Annecy eutrophication was limited to a mesotrophic state (Druart and Pelletier, 1998) at the end of the 1960s (maximum [TP] $<20 \mu \mathrm{g} \mathrm{L}^{-1}$ ). Current [TP] is $<6 \mu \mathrm{g} \mathrm{L}^{-1}$ (INRA long-term observatory database). In contrast, restoration measures started only during the 1970s for lakes Geneva and Bourget, while these lakes were already eutrophic (maximum [TP] $=130 \mu \mathrm{g} \mathrm{L}^{-1}$ in 1977 in lake Bourget and $90 \mu \mathrm{g} \mathrm{L}^{-1}$ in 1979 in lake Geneva, INRA long-term observatory database, winter mean). The settlement of water-treatment plants (early 1970s around lake Geneva and late 1970s in lake Bourget), the ban of P-containing detergents (in 1986 in Switzerland, Rapin et al., 1989; and 2007 in France, Lazzarotto et al., 2011) and the diversion, in 1981, of treated sewage waters into the Rhône river to preserve lake Bourget (Jacquet et al., 2005) successfully resulted in TP reductions (in 2010, TP were $17 \mu \mathrm{g} \mathrm{L}^{-1}$ in lake Bourget and $23 \mu \mathrm{g} \mathrm{L}^{-1}$ in lake Geneva).

Lake Geneva monitoring survey (managed by the International Commission for the Protection of Lake Geneva Waters and the INRA, French National Institute for Agricultural Research) started in 1957. Sampling for the long-term monitoring has been performed at the deepest point of the lake (SHL2). Until 1980, sampling occurred once a month, and biweekly during the stratified season (March-November) since 1981. Water samples dedicated to phytoplankton analysis were collected in the 0-10 m depth water layer from 1974 to 1999 , which was extended down to 0-20 m depth from 2000. Microscopic 
analyses have been performed following the Utermohl method (Utermohl, 1958), now standardised at the European level (AFNOR, 2006). After classical Utermohl determination under inverted microscope, a part of the sample has been treated with hydrogen peroxide for diatom preparation following the European standard for diatom sample treatment and determinations with a $1000 \times$ magnification (AFNOR, 2004). The chemical concentration of TP has been measured using the acid molybdate method (AFNOR, 1982). Annual averages have been calculated for the 0-20 m depth water layer, i.e. phytoplankton sampling depth.

Long-term routine monitoring surveys started in 1996 for lake Annecy (managed by the Intercommunal Association of Lake Annecy and INRA) and 2004 for lake Bourget (Lake Bourget Water Agency and INRA). From the late 1960's and until the settlement of the long-term monitoring, TP had not been measured for every year (available data for lake Annecy: 1969-1981 and 1991-2007; lake Bourget: 1970, 1971 and 2004-2007). Such data were available from the French Alpine Lakes Long-Term Observatory Database (Database SOERE-INRA of Thononles-Bains, France). As in lake Geneva, all the data have been collected at the deepest point of these two lakes and annual averages have been calculated for the $0-20 \mathrm{~m}$ depth water layer.

\section{Lake coring and sediment dating}

Several short sediment cores were collected from the deepest point of each lake between 2004 and February 2009 using a quadruple gravity corer (UWITEC, Mondsee, Austria). Sediment dating was performed from one master core for each lake using radiometric methods ${ }^{(210} \mathrm{Pb},{ }^{226} \mathrm{Ra},{ }^{137} \mathrm{Cs}$ and ${ }^{241} \mathrm{Am}$ activities$)$ and counting of annual laminations, which provided accurate chronologies for high-resolution sampling in the three lakes. All working cores (those on which palaeolimnological analyses were performed) were sampled according to the annual laminations, with the same temporal precision (annual or, at most, triennial resolution) and correlated to the master core using lithological tie points and lamina counting performed on both master and working cores (Zolitschka, 2003). Such high-temporal resolution and accuracy were required in order to integrate instrumental and palaeo-data from multiple cores.

\section{Fossil diatom preparation and counting}

Diatom counts were performed on 32 (lake Annecy, core LDA09P302D2), 48 (lake Bourget, core LDB09P302D1) and 65 (lake Geneva, cores LEM10P601 and LEM11P14A) subsamples. sub-samples were weighted before and after drying $\left(60^{\circ} \mathrm{C}\right.$ during $\left.48 \mathrm{~h}\right)$. After classical $\mathrm{H}_{2} \mathrm{O}_{2}-\mathrm{HCl}$ digestion (Renberg, 1990), di- atoms were mounted in Naphrax on optical microscope slide (one slide per core sample). On each slide, at least 400 valves were counted and identified by light microscopy using phase contrast or differential interference contrast with $1000 \times$ magnification. In order to keep an homogeneous determination in the different samples, several pictures were taken for each species. The identifications and counts followed the European standard method (AFNOR, 2004). Determinations were carried out using the Krammer and Lange-Bertalot floras (1986, 1988, 1991a, 1991b) and other specialized bibliographical data when needed.

\section{Data analyses}

\section{Diatom stratigraphy}

To reveal the timing of major changes in the communities, chronological clustering analyses, computed from Bray-Curtis dissimilarity indexes, were performed (CONISS in R package rioja, Juggins, 2009). The brokenstick approach (Bennett, 2006) was used to assess the number of statistically significant biozones.

\section{Comparison of limnological and palaeolimnological diatom records}

For lake Geneva, changes over time in the taxonomic compositions (expressed as species relative abundances per year) were compared between the limnological and palaeolimnological records over a 30-year period (19772007). Correlations between the two datasets were detected using a non-parametric Mantel test (Mantel, 1967) performed on two Bray-Curtis distance matrices (Ginkgo software, (De Caceres et al., 2007). The Mantel test was performed using xlstat (http://www.xlstat.com, Addinsoft)

To explore the differences between palaeolimnological and limnological countings, the Indval Method (Dufrene and Legendre, 1997) was performed using PCOrd 5 (McCune and Mefford, 2006) to define which species are more characteristics for the limnological or the palaeolimnological samples.

\section{Transfer functions}

Annual mean TP concentrations were reconstructed from a diatom inference model based on 86 surface sediment samples collected from sub-Alpine lakes in the Alps region (Wunsam and Schmidt ,1995). This calibration dataset includes 86 lakes in the Alpine region (Italy, Germany and Austria) spanning a large gradient in altitude (198-1763 m asl), maximum depth (2-270 m) and mean annual TP (2-266 $\left.\mu \mathrm{g} \mathrm{L}^{-1}\right)$. The model was calibrated using log-transformed TP data. The original calibration presented by Wunsam and Schmidt (1995) using tolerance weighted WA showed a bootstrapped root mean square error of the 
prediction (RMSEP) of 0.346 log units. Bootstrapped average and maximum bias were 0.009 and $0.86 \log$ units, respectively. The selected model was then applied to the diatom biostratigraphy of each lake. The diatom-inferred TP reconstructions (DI-TP) reconstructions were performed using program C2 - version 1.7.2, (Juggins, 2007). Several models were tested: weighted averaging with classical deshrinking (WAcla regression), weighted averaging with inverse deshrinking (WAinv regression) (Ter Braak and van Dam, 1989), weighted averaging partial least squares regression (WAPLS) (Ter Braak and Juggins, 1993), modern analogue technique (MAT) with squared chord distance and five analogues (Overpeck et al., 1985); and their relative performances were estimated using $\mathrm{r}^{2}$ and the root mean square error of prediction (RMSEP) calculated using a cross validation method (bootstrapping, 500 permutations) on the calibration dataset. The same bootstrapping procedure was used to calculate the standard error of the prediction of the core samples.

The diatom-inferred TP reconstructions were compared to TP limnological data, and also to palaeolimnologically reconstructed changes in Daphnia abundances (Alric, 2012) since these are known to be good indicators of TP dynamics (DeMott and Gulati, 1999).

\section{RESULTS}

\section{Comparison of limnological and palaeolimnological data in lake Geneva}

The temporal changes in the relative abundances of the most commonly occurring species over the 1977-2007 time-period in lake Geneva are presented in Fig. 1. Over the 1977-2007 time-period in lake Geneva, a total of 80 taxa were present in the limnological dataset and 114 in the palaeolimnological one. A comparison of the species relative abundances in the limnological data and palaeolimnological data highlighted some differences: Asterionella formosa, Cyclotella costei and Diatoma tenuis relative abundances were higher in limnological data, and, in contrast, Stephanodiscus binderanus and S. minutulus had lower relative abundances than in the palaeolimnological data (between 1989 and 1996).

The Mantel test showed that the two datasets were significantly correlated $(\mathrm{P}<0.0001)$ but the strength of the relationship was low $(\mathrm{r}=0.498)$. Here, only 52 taxa, which had a relative abundance $>2 \%$, were kept for the Indval method. Among these taxa, 38 species were typical for only one of the two datasets (Tab. 1). These 38 species were separated following their life form (benthic or planktonic) according to Berthon et al. (2011) and Rimet and Bouchez, $2012 \mathrm{~b}$. The proportion of benthic species is very low and did not exceed 9\% in lake Annecy and lake Bourget and $6 \%$ in lake Geneva. This classification underlined that the majority of the species only present in the palaeolimnological dataset were benthic species (Tab. 1 - group 1). Only one benthic species (Achnanthidium minutissimum (Kutzing) Czarnecki) was present in both datasets (group 2) but with a higher relative abundance in the palaeolimnological data. Three benthic taxa were detected only in the limnological dataset (Fragilaria capucina var. radians which is principally recognizable in living samples using the star shape of the colonies, Navicula sp. and Nitzschia sp. - group 3). Among the planktonic taxa, again, the majority belonged to group 1 , seven belonged to group 3 and only two

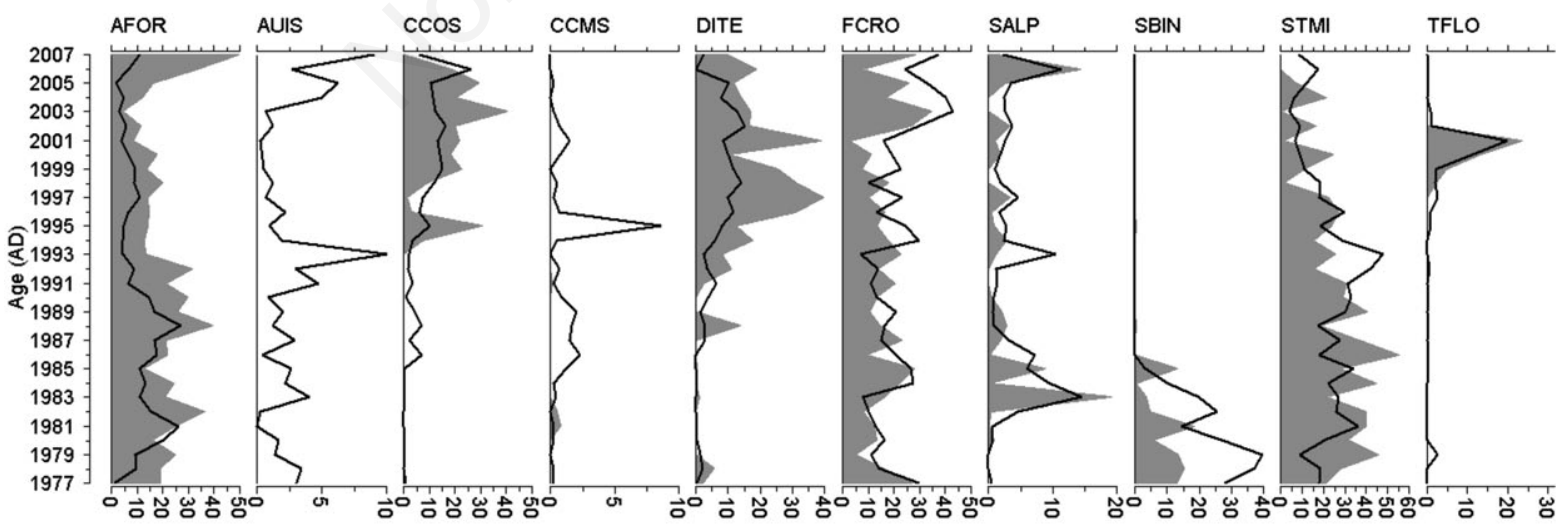

Fig. 1. Comparison of the major planktonic diatom species in the fossil diatom record and in the phytoplankton samples (relative abundances in the diatom community percentage) of lake Geneva 1977-2007. Black line, palaeolimnological data; grey silhouette, phytoplankton data; AFOR, Asterionella formosa Hassall; AUIS, Aulacoseira islandica (Muller) Simonsen; CCOS, Cyclotella costei Druart \& Straub; CCMS, Cyclotella comensis Grunow in Van Heurck; DITE, Diatoma tenuis Agardh; FCRO, Fragilaria crotonensis Kitton; SALP, Stephanodiscus alpinus Hustedt in Huber-Pestalozzi; SBIN, Stephanodiscus binderanus (Kutzing) Krieger; STMI, Stephanodiscus minutulus (Kutzing) Cleve and Moller; TFLO, Tabellaria flocculosa (Roth) Kutzing. 
were present in the two datasets and in higher abundance in the limnological dataset (Asterionella formosa and Diatoma tenuis - group 4).

\section{Changes in the fossil diatom assemblages}

Fossils from 145, 239 and 203 diatom species for, respectively, lakes Annecy, Bourget and Geneva, were recovered from the cores. Six species represented more than $80 \%$ of the total planktonic frustules in lake Annecy, and ten species for lake Bourget and lake Geneva (Fig. 2). The oldest core samples in the three lakes were rich in $C y$ clotella species. The relative abundance and the diversity of Cyclotella valves decreased over the time. This trend was partly reversed in the most recent samples. Another common feature was a generally increasing contribution of Fragilaria crotonensis (Kitton) over time.

No diatom valves could be detected in the lowermost part of the core of lake Annecy, corresponding to time periods prior to the early 1930s. Cyclotella costei (Druart \& Straub) [synonym of Cyclotella cyclopuncta Håkansson \& Carter (Houk et al., 2010)] and Fragilaria crotonensis were the dominant species, making, on average, up to $70 \%$ of the fossil remains. Between 1937 and 2007, chronological clustering identified six biozones (a1-a6). Major shifts in the fossil diatom communities were identified in 1941-1942, 1950-1951, 1963-1964, 1967-1968

Tab. 1. IndVal method results. Only species with a significant P-value $(<0.05)$ are presented. These species are characteristics of one of the two compared datasets. The species of the group 1 (last column) are only present in the palaeolimnological dataset, the species of group 2 are present in the two datasets but are characteristics of the palaeolimnological dataset, the species of group 3 are only present in the limnological dataset and the species of group 4 are present in the two datasets but are characteristics of the limnological dataset.

\begin{tabular}{|c|c|c|c|}
\hline \multirow[t]{2}{*}{ Species } & \multicolumn{2}{|c|}{ P value } & \multirow[t]{2}{*}{ Group } \\
\hline & Limnological dataset & Palaeolimnological dataset & \\
\hline \multicolumn{4}{|l|}{ Benthic species } \\
\hline Achnanthidium minutissimum (Kutzing) Czarnecki & & 0.0284 & 2 \\
\hline Amphora pediculus (Kutzing) Grunow & & 0.0002 & 1 \\
\hline Cocconeis placentula Ehrenberg var. placentula & & 0.0052 & 1 \\
\hline Cymatopleura solea (Brebisson in Breb. \& Godey) W.Smith var. solea & & 0.0018 & 1 \\
\hline Diatoma moniliformis Kutzing & & 0.0016 & 1 \\
\hline Encyonema minutum (Hilse in Rabh.) D.G. Mann & & 0.0002 & 1 \\
\hline Fragilaria capucina Desmazieres var. capucina & & 0.0002 & 1 \\
\hline Fragilaria capucina Desmazieres var. radians (Kutzing) Lange-Bertalot & 0.0002 & & 3 \\
\hline Fragilaria capucina Desmazieres var. vaucheriae (Kutzing) Lange-Bertalot & & 0.0234 & 1 \\
\hline Fragilaria mesolepta Rabenhorst & & 0.0022 & 1 \\
\hline Gomphonema pumilum (Grunow) Reichardt \& Lange-Bertalot & & 0.049 & 1 \\
\hline Navicula cryptotenella Lange-Bertalot & & 0.011 & 1 \\
\hline Navicula reichardtiana Lange-Bertalot var. reichardtiana & & 0.258 & 1 \\
\hline Navicula sp. & 0.0002 & & 3 \\
\hline Navicula subrotundata Hustedt & & 0.004 & 1 \\
\hline Nitzschia dissipata (Kutzing) Grunow var. dissipata & & 0.002 & 1 \\
\hline Nitzschia fonticola Grunow in Cleve et Muller & & 0.0002 & 1 \\
\hline Nitzschia sp. & 0.0002 & & 3 \\
\hline Staurosira mutabilis (Wm Smith) Grunow & & 0.0006 & 1 \\
\hline \multicolumn{4}{|l|}{ Planktonic species } \\
\hline Asterionella formosa Hassall & 0.0002 & & 4 \\
\hline Aulacoseira ambigua (Grunow) Simonsen & & 0.0004 & 1 \\
\hline Aulacoseira granulata (Ehr.) Simonsen var. angustissima (Muller) Simonsen & 0.0002 & & 3 \\
\hline Aulacoseira islandica (Muller) Simonsen & & 0.0002 & 1 \\
\hline Aulacoseira islandica (Muller) Simonsen subsp. helvetica (Muller) Simonsen & 0.0002 & & 3 \\
\hline Cyclotella comensis Grunow in Van Heurck & & 0.0002 & 1 \\
\hline Cyclotella delicatula Hustedt & & 0.0002 & 1 \\
\hline Cyclotella sp. & 0.0004 & & 3 \\
\hline Diatoma tenuis Agardh & 0.0224 & & 4 \\
\hline Discostella pseudostelligera (Hustedt) Houk and Klee & & 0.0086 & 1 \\
\hline Discostella stelligera (Cleve et Grun.) Houk and Klee & & 0.0002 & 1 \\
\hline Fragilaria ulna (Nitzsch.) Lange-Bertalot var. acus (Kutz.) Lange-Bertalot & 0.0002 & & 3 \\
\hline Fragilaria (Ulnaria) ulna Sippen angustissima (Grun.) Lange-Bertalot & 0.0002 & & 3 \\
\hline Nitzschia acicularis (Kutzing) W.M.Smith & 0.0002 & & 3 \\
\hline Stephanodiscus irregularis Druart. Reymond Pelletier and Gasse & & 0.0014 & 1 \\
\hline Stephanodiscus parvus Stoermer and Hakansson & & 0.0002 & 1 \\
\hline Stephanodiscus species & & 0.0106 & 1 \\
\hline
\end{tabular}


and 1976-1977. Before the early 1950s (biozones a1 and a2), the fossil diatom community was the most diverse, with notable amounts of Cyclotella distinguenda var. distinguenda Hustedt, Cyclotella comensis Grunow in Van Heurck and Stephanodiscus minutulus (Kutzing) Cleve \& Moller. Cyclotella costei and Fragilaria crotonensis were dominant in all counts from the 1950s (biozones a3 to a6). In the 1950s-60s (biozone a3), the relative abundance of
Cyclotella costei exceeded $60 \%$ but the relative abundance of Fragilaria crotonensis increased up to $45 \%$ from the 1960s, so that the relative abundance of these two species were comparable within the biozones a4-a5. Increasing abundances of Fragilaria crotonensis in biozones a4-a5 occurred with increased amounts of Stephanodicus parvus Stoermer et Håkansson. The diatom composition in the most recent samples (biozone a6)
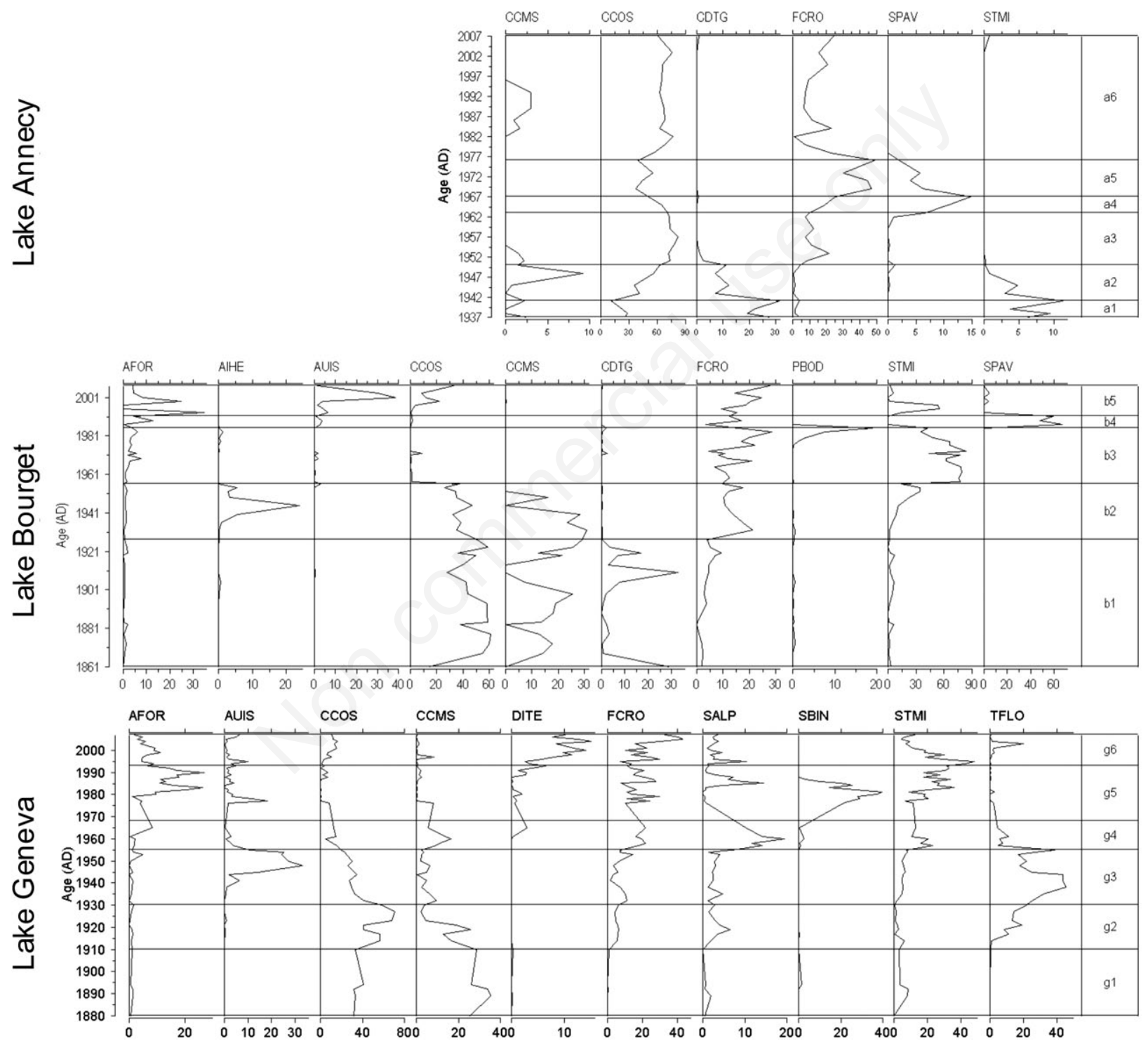

Fig. 2. Summary diatom stratigraphies of the most common taxa (relative abundances) in the three studied lakes. AFOR, Asterionella formosa Hassall; AIHE, Aulacoseira islandica (Muller) Simonsen subsp. helvetica (Muller) Simonsen; AUIS, Aulacoseira islandica (Muller) Simonsen; CCOS, Cyclotella costei Druart \& Straub; CCMS, Cyclotella comensis Grunow in Van Heurck; CDTG, Cyclotella distinguenda var. distinguenda Hustedt; DITE, Diatoma tenuis Agardh; FCRO, Fragilaria crotonensis Kitton; PBOD: Puncticulata bodanica (Grunow in Schneider) Håkansson; SALP, Stephanodiscus alpinus Hustedt in Huber-Pestalozzi; SBIN, Stephanodiscus binderanus (Kutzing) Krieger; SPAV, Stephanodiscus parvus Stoermer and Håkansson; STMI, Stephanodiscus minutulus (Kutzing) Cleve and Moller; TFLO, Tabellaria flocculosa (Roth) Kutzing. 
strongly resembled that of biozone a3. Changes in community structure were more striking in lake Bourget. Five biozones were identified (b1-b5), with transitions occurring in 1926, 1956, 1986, and 1991. In biozone b1, the community was dominated by Cyclotella costei, $C$. comensis and $C$. distinguenda var. distinguenda. In biozone b2 (1930s-1950s), C. distinguenda var. distinguenda disappeared while the contributions of Stephanodiscus minutulus and Fragilaria crotonensis increased. Biozone b3 (late 1950-late 1980s) was almost exclusively represented by these two species. Biozones b4-b5 saw the reappearance of some of the Cyclotella species that were previously detected in biozones b1-b2 such as the decreasing abundances of Stephanodiscus minutulus (except for a peak in the 1990s). However, the contributions of species that were detected only at very low levels before, i.e. Asterionella formosa Hassall, Aulacoseira islandica (O. Muller) Simonsen ssp. helvetica (O.M.) Simonsen and Stephanodiscus parvus, substantially increased in biozones b4-b5. Hence, the diatom composition in the most recent samples of b5 was not similar to any of those observed in the preceding biozones.

In lake Geneva, six biozones were identified (g1-g6), with transitions in 1910, 1930, 1955, 1968 and 1994. Cyclotella costei and Cyclotella comensis were very abundant in the biozones g1-g2. The main difference between the two biozones was due to an increased contribution of Tabellaria flocculosa (Roth) Kutzing, F. crotonensis and S. alpinus for the biozone g2. The community then shifted in the early 1930s to dominance by Tabellaria floculosa, along with the appearance of Fragilaria crotonensis, Aulacoseira islandica ssp. helvetica and Stephanodiscus minutulus (g3). The biozone g4, between the mid 1950s and the early 1970s, was characterized by dominance of S. minutulus, S. alpinus and F. crotonensis. Stephanodiscus species were very abundant by the end of the 1980s (middle of the biozone g5) making up to $60 \%$ of the total community. In biozone g6, some Cyclotella species ( $C y$ clotella costei), which had disappeared in the previous biozones, became more abundant. The community was, however, dominated by F. crotonensis $(40 \%)$ and Diatoma tenuis Kutzing (20\%), which had been rare so far. Tabellaria floculosa represented $20 \%$ of the community in 2000 . Because of their richness in the three latter species, the most recent samples of the biozone g6 were very different from the rest of the core.

\section{Transfer functions}

In comparison with the WA and WAPLS models, MAT models performed poorly. There were no relevant differences between WA and WAPLS model performances. The RMSEP of the models compared well with the standard error of the prediction (SEP) calculated on the core samples (Tab. 2). Results presented in Fig. 3 are those obtained using the $\mathrm{WA}_{\text {cla }}$ regression for lake Annecy and lake Geneva and using the $\mathrm{WA}_{\text {inv }}$ regression for lake Bourget. In the three lakes, for each sample, the proportion of taxa present in the calibration dataset was high: $90 \%$ in lake Annecy, $91 \%$ in lake Bourget, and lower in lake Geneva: 83\% (average value).

In lake Annecy, before 1945, the DI-TP concentration varied between 10 and $15 \mu \mathrm{g} \mathrm{L}^{-1}$. DI-TP values were transiently lower (around $7 \mu \mathrm{g} \mathrm{L}^{-1}$ ) during the following 14 years but increased back to $11 \mu \mathrm{g} \mathrm{L}^{-1}$ between 1963 and 1976. The diatom-inferred TP reconstructions values decreased back after this light mesotrophic episode up to the top of the core (around $8 \mu \mathrm{g} \mathrm{L}^{-1}$ ). The diatom-inferred TP reconstructions values were consistent with instrumental data and adequately tracked the decrease in $\mathrm{P}$ concentrations over the last 30 years. The temporal dynamics in Daphnia abundance generally matched that of DI-TP, with maxima reached between the mid 1960s and 1970s, except for the period before the 1940s for which very low Daphnia abundance did not support the relatively high DI-TP. In lake Bourget, before 1952, DI-TP concentrations were low (mean value $=12 \mu \mathrm{g} \mathrm{L}^{-1}$ ). The diatom-inferred TP reconstructions values dramatically increased from the early 1950s to reach $68 \mu \mathrm{g} \mathrm{L}^{-1}$ in 1957. The diatom-inferred TP reconstructions transiently decreased and fluctuated between $36-73 \mu \mathrm{g} \mathrm{L} \mathrm{L}^{-1}$ to reach a maximum of $80 \mu \mathrm{g} \mathrm{\textrm {L } ^ { - 1 }}$ in 1973. Between 1973 and 2007, DI-TP dropped to $14 \mu \mathrm{g}$

Tab. 2. Performance of the different tested transfer function models.

\begin{tabular}{lcccccc}
\hline Reconstruction method & $\mathrm{r}^{2}$ & \multicolumn{2}{c}{ Lake Annecy } & \multicolumn{2}{c}{ Lake Bourget } & \multicolumn{2}{c}{ Lake Geneva } \\
Model & RMSEP & $\begin{array}{c}\text { Deepest } \\
\text { slices SEP }\end{array}$ & $\begin{array}{c}\text { Model } \\
\text { RMSEP }\end{array}$ & $\begin{array}{c}\text { Deepest } \\
\text { slices SEP }\end{array}$ & $\begin{array}{c}\text { Model } \\
\text { RMSEP }\end{array}$ & seest \\
slices SEP
\end{tabular}

$r^{2}$, bootstrapped squared correlation between inferred and observed values; Model RMSEP, root mean squared error of prediction evaluated through bootstrap; deepest slices SEP, standard error of the prediction in the deepest slices of each core; $W A_{\text {cla }}$, weighted averaging with classical deshrinking; $W A_{\text {in, }}$ weighted averaging with inverse deshrinking; WAPLS, weighted averaging partial least squares regression; MAT, modern analogue technique. Unit: $\log ^{10}$ total phosphorus concentration. 

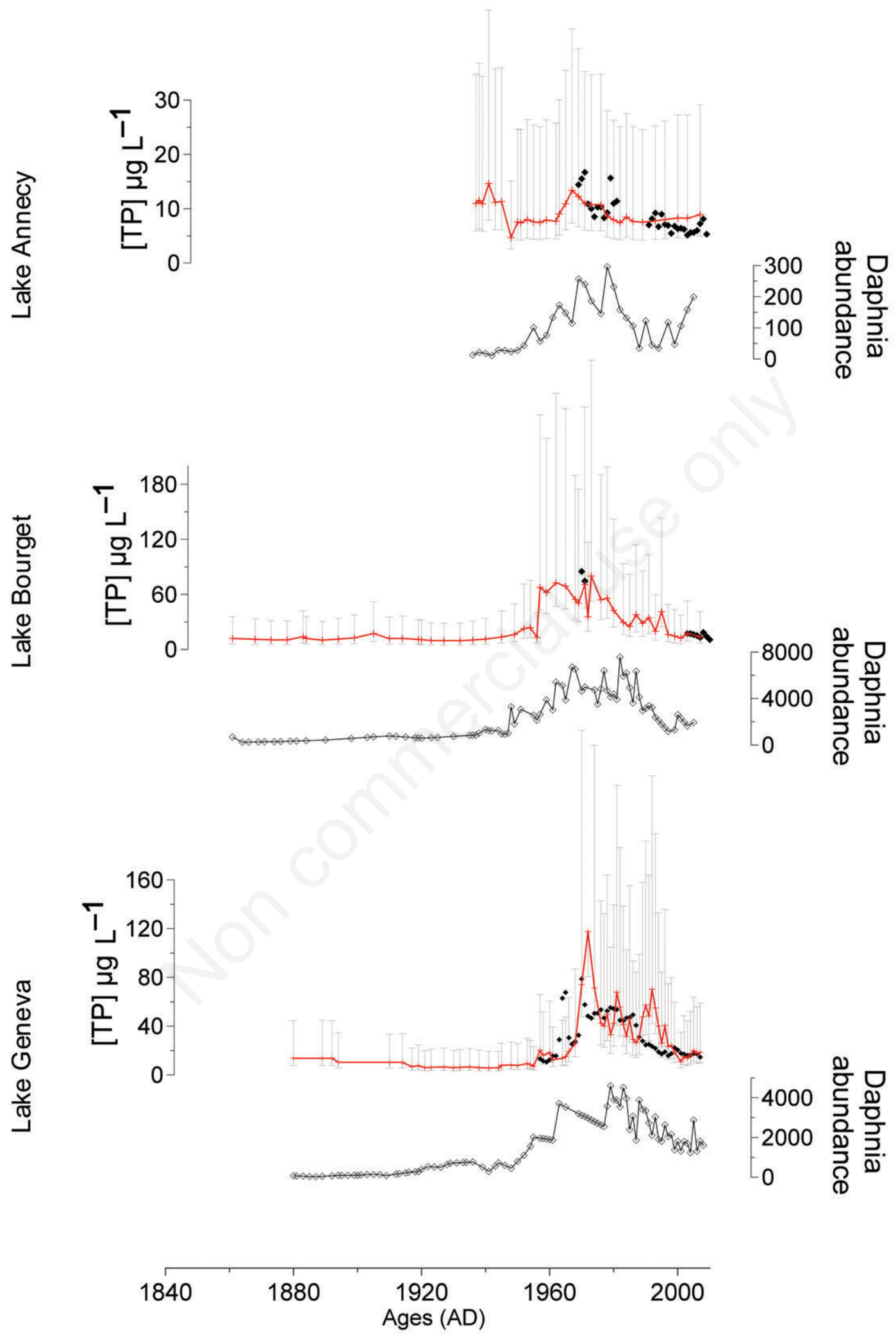

Fig. 3. Diatom-inferred total epilimnetic phosphorus $\left(\mu \mathrm{g} \mathrm{L}^{-1}\right)$ (black line, bars indicate bootstrap estimated standard error of the prediction) compared with long-term measured epilimnetic phosphorus concentrations in the study lakes (circle, annual values) and abundance of fossil Daphnia per gram of dry sediment. 
$\mathrm{L}^{-1}$ in 2007, consistent with monitored data. Daphnia abundance was generally consistent with that of DI-TP. Daphnia maxima matched those in DI-TP. However, it seems that Daphnia abundance increased from the 1940s: i.e., a decade earlier than the first detected increase in DI-TP. In lake Geneva, DI- TP concentration was low and fluctuated between 6 and $14 \mu \mathrm{g} \mathrm{L}^{-1}$ before 1955. In 1957, values started to increase, to reach $120 \mu \mathrm{g} \mathrm{L}^{-1}$ in 1974 . The general dynamics of DI-TP during eutrophication mirrored that of the monitored data, except that DI-TP tended to over-estimate the P maximum. As for lake Bourget, the general dynamics of Daphnia abundances were consistent with DI-TP, except that they started to increase a decade earlier. The diatom-inferred TP reconstructions values in lake Geneva decreased from this peak, to reach $19 \mu \mathrm{g} \mathrm{L}^{-1}$ in 2007, except for a period of very high DI-TP in the 1990s that was not corroborated by monitored TP data, nor by reconstructed changes in Daphnia abundance.

\section{DISCUSSION}

\section{Fidelity of fossil records}

Comparisons of palaeolimnological to limnological diatoms countings are important to evaluate the accuracy and relevancy of palaeoenvironmental inferences (Marchetto and Musazzi, 2001). These comparisons allowed an assessment of the fidelity of fossil records and the potential bias arising from taphonomic processes occurring before and after the remains are archived in the sediment. In deep and large sub-Alpine lakes, representation of living diatom communities by deep-water sedimentary diatom assemblages has been already studied by Marchetto and Musazzi (2001), who compared relative abundance of six selected planktonic species in plankton counts and sediment samples in lake Maggiore between 1981 and 1998. Besides, Wessels et al. (1999) used the few historical phytoplankton data present in the literature to check whether sediment data reflect planktonic diatom community in lake Constance from 1955, but the comparison performed was based on few species and on sporadic sampled years. A more powerful approach was possible herein because lake Geneva has been carefully monitored for 30 years, and also because the lake's annually-laminated sediment can be dated with very high accuracy. These kinds of diachronic comparison performed on long time periods for a single lake are rare because limnological monitoring often contains temporal gaps.

Different potential errors inherent to the used palaeolimnological and limnological methods can be observed. Sediment records can suffer from taphonomic biases and errors in the cores samples dating (Battarbee et al., 2005). However, first, the temperature and $\mathrm{pH}$ conditions, which are considered the most important parameters for good valves conservation in sediments (Battarbee et al., 2002; Flower, 1993), allowed a good preservation of diatoms valves, in the three studied lakes. Yet, in lake Annecy, before 1937 , no diatoms valves could be detected in the sediment samples. Druart and Pelletier (1998) encountered that same limits while conducting on a long-term palaeolimnological study on lake Annecy and gave two hypothesis: i) the very low trophic level could restrict the algal production; ii) the sediment are rich in detrital particles that could dilute the organism rests. Second, radiometric methods and counting of annual laminations provided accurate chronologies (radiometric methods: \pm 5 years; counting of annual laminations: \pm 1 year). Furthermore, cores were meticulously studied to show irregularities in sediment deposit (e.g., flood events have been spotted) and we chose to work at the deepest part of the three lakes to limit the effect of phenomenon as bioturbation within the sediment column, which can provide a worse representation of the diatom communities. In limnological methods, biases can appear when the protocol is not strictly respected or when the operators change: differences in result can be observed in inter-comparison exercises [Prygiel et al., 2002); External Quality Assessment Trials Phytoplankton (EQAT, www.planktonforum.eu]. The participation of our limnological database operators to this kind of exercises allows a good use and respect of the standard.

The Mantel test showed that the palaeolimnological and limnological datasets were highly correlated, hence highlighting a high compositional fidelity of the sediment archive in lake Geneva. Good preservation has also been shown for Cladoceran subfossils in these deep subAlpine lakes and is attributed to rapid and direct sedimentation processes in an environment relatively undisturbed by sediment resuspension and transportation (Alric and Perga, 2011). Nevertheless, differences between the two datasets may arise from three non-exclusive processes. First, diversity was greater in the palaeolimnological dataset than in the limnological dataset of lake Geneva. Ecological groups enabling discrimination between benthic and planktonic species, as designed by Berthon et al. (2011) and Rimet and Bouchez (2012b), were used to interpret the Indval Method results (even if these study were based on river assemblages, we believe that the principle of classification, based on genera life history traits, remains valid in lakes). Results showed that the higher diversity of the palaeolimnological record could be attributed to the presence of rather numerous benthic species, that might arise from lateral transport of diatom remains from littoral areas (sediment focusing (Blais and Kalff, 1995; Likens and Davis, 1975). Overall though, this bias was kept low, since it represented $<10 \%$ of the total community abundance and tends to be limited by geomorphology of these deep large lakes with restricted littoral areas, which are $7 \mathrm{~km}$ from the sampling site in lake Geneva. Second, some species were found only in the limnological data, 
which could be explained by the constant evolution of diatom taxonomy and the use of different taxonomic books over time (Rimet and Bouchez, 2012a). It could also be explained by operator determination skills in the case of Fragilaria and Aulacoseira, since both genera encompass several morphologically similar species that can be confused. Third, two dominant species (Asterionella formosa and Diatoma tenuis) were under-estimated in the palaeolimnological dataset relative to the limnological dataset. These species have a very thin siliceous skeleton and might be more sensitive to taphonomic processes during sedimentation. Their preservation might be lower than for other species with thicker frustules, which might explain why valves detected on the slides were broken. Such underestimations of the abundance of Asterionella formosa and Diatoma tenuis in profundal core samples were also observed by Marchetto and Musazzi (2001).

\section{Lake trophic histories}

As mentioned above, fossil diatoms in lake Annecy cannot be used to reconstruct the trophic history before 1937, because they were not preserved in the sediments. Lake Annecy did not reach a high level of eutrophication (maximum TP concentration $15 \mu \mathrm{g} \mathrm{L}^{-1}$ in 1966 and 1970 - winter mean, limnological data) but a slight decrease in Cyclotella costei and a replacement by more eutrophic species, namely Stephanodiscus parvus were yet observed. The increase in DI-TP concentration has been stronger in lake Bourget and lake Geneva according major shifts in the fossil diatom communities, most notably the replacement of Cyclotella species by mainly Stephanodiscus minutulus. These patterns were partially reversed following lake restoration. In lake Geneva the transition between the oligotrophic and eutrophic phases seemed to be slower than in lake Bourget, with periods during which mesotrophic species as Tabellaria floculosa and Diatoma tenuis developed (Rimet et al., 2009). Lakes Bourget and Geneva underwent a similar trophic history and diatom species succession to that reported for lake Maggiore (Italy) and lake Constance (Germany/Switzerland boundary) while that of lake Annecy was more limited. Indeed, in the latter, the species successions has been less contrasted since the abundance of Cyclotella costei decreased but the species could maintain in the diatom community, in contrast to lake Bourget and lake Geneva, where they disappeared. Similarly to lake Maggiore and lake Constance (Marchetto et al., 2004), the trophic status of lake Bourget and lake Geneva are still higher than before eutrophication. The composition of the diatom assemblages in these two lakes today is markedly different from that of the pre-eutrophication period with particularly lower abundance of Cyclotella comensis in the recent sediment and the presence of Asterionella formosa and Diatoma tenuis (mesotrophic species) in lake Geneva. Re-oligotrophication is more advanced in lake Maggiore where Cyclotella comensis is currently abundant (Marchetto et al., 2004).

\section{Total phosphorus reconstructions}

In spite of the annual variability in TP concentration in lakes, the annual mean TP concentration measured in the three study lakes compares well with the DI-TP values. Apart some sporadic points, the difference between measured and inferred TP is markedly lower than the standard error of the prediction estimated using the bootstrapping techniques. This pattern was also found by, for example, Marchetto and Bettinetti (1995) in other deep lakes, and it is probably due to the large morphometric heterogeneity of the lakes included in the calibration data set. In fact, in the bootstrapping procedure, the error component specific to each fossil sample (v1 in Birks et al., 1990) is markedly smaller than the component due to the imperfection in the calibration procedure (v2 in Birks et al., 1990). Indeed, there are not enough large deep lakes in Europe to build a specific data set, so that Wunsam and Schmidt (1995) enlarged their calibration data set with shallower lakes. A consequence is an inflated noise in the transfer function. Nevertheless, DI-TP values were very close to the measured TP for samples which diatom composition was very similar to those used for the calibration. In contrast, in samples rich in small Stephanodiscus, which have no modern analog in the calibration data set, the DI-TP values were quite different from the measured values.

$\mathrm{WA}_{\text {cla }}$ reconstruction models provided TP values closest to the limnological data and the most realistic in relation to the known history of the lakes Annecy and Geneva during the last century (limnological data+Daphnia abundance reconstruction). In contrast, the most adequate model was the $\mathrm{WA}_{\text {inv }}$ for lake Bourget. WAPLS did not provide satisfactory reconstructions: for instance, in lake Bourget, between 1860 and 1940, the WAPLS reconstruction lead to marked fluctuations between 12 and $90 \mu \mathrm{g} \mathrm{L}^{-1}$ which were not supported by others proxies such as cladocerans (Alric, 2012). Furthermore, WAPLS, as an inverse approach, seems to perform best if the fossil samples are similar in composition to samples in the central part of the calibration data (Birks, 1998), which was not the case here. A high abundance of some species in the dataset used to calculate the DI-TP concentration caused some overestimations or underestimations compared with monitored TP (Wunsam and Schmidt, 1995). The overestimated values corresponded to the time periods when the relative abundance of Stephanodiscus species was very high although the $\mathrm{WA}_{\text {cla }}$ model seemed to be less sensitive to this problem. DI-TP values were higher than expected between 1937 and 1945 in lake Annecy, and in 1972 and between 1989 and 1996 in lake Geneva. This over-estimation by the model has been observed in previous studies. Stephanodiscus minutulus was very abundant during the 1980s in 
the palaeolimnological record of lake Maggiore (Marchetto et al., 2004) while Stephanodiscus spp. relative abundance was higher than $30 \%$ in the Esthwaite Water and the Windermere South Basin diatom community (Bennion et al., 2005). Bennion (1995), in lake Mondsee, showed the same overestimation due to the same Stephanodiscus species and speculated it could be explained by the high abundances of these species in the most eutrophic lakes of the calibration dataset. It should also be noted that, between 1989 and 1996, in lake Geneva, taphonomic bias might cause an over-estimation of Stephanodiscus minutulus (Fig. 1). Cyclotella costei, which was very abundant in the three studied lakes, may have the opposite effect since high abundances in the sediment appear to be associated with TP underestimations. Then, assuming that mesotrophic species (Tabellaria floculosa and Diatoma tenuis) increasing abundances do not cause any progressive increase in DI-TP concentration in lakes Bourget and Geneva, the model may not account sufficiently for these species. As a result, the reconstruction using this transfer function does not detect small fluctuations of TP concentrations at low TP levels $\left(<10 \mu \mathrm{g} \mathrm{L}^{-1}\right)$, as evidenced by the comparison with Daphnia biostratigraphies. The consequence is that the model cannot date accurately the early beginning of eutrophication in lakes Bourget and Geneva, hence partially limiting the accuracy of the TP reference conditions.

\section{Reference conditions and present state}

Reference conditions are determined as the state observed before the industrialisation and agricultural intensification (but they do not equate to the pristine state because the anthropogenic impacts started before) (Bennion et al., 2005). Using the transfer function result, as we said in the 4.3 section, we cannot define precisely the references conditions for TP concentration in the three studied lakes. Furthermore, for lake Annecy, the absence of diatoms in the lowermost section of the core (before 1937 AD) limited the extent of the record. Average DI-TP concentrations values calculated over the known pre-eutrophication period (lake Annecy $_{1938-1950}: 10 \mu \mathrm{g} \mathrm{L}^{-1}$; lake Bourget ${ }_{1861-1950}: 11 \mu \mathrm{g} \mathrm{L}^{-1}$; lake Geneva ${ }_{1880-1950}: 8 \mu \mathrm{g} \mathrm{L}^{-1}$ ), are slightly higher than values observed in lake Maggiore and lake Constance (Marchetto et al., 2004; Wessels et al., 1999) and this might arise from the model limits as specified above.

The current diatom communities compositions in the three studied lakes are still different from those observed for the defined reference conditions, with, for instance, lower abundances of Cyclotella. However, TP concentration is not the only parameter that can drive changes in the diatom communities. For instance, increasing abundance of Fragilaria crotonensis - which is typically a thermophilic species in these lakes (Rimet et al., 2009) - over the most recent years of the studied period may be attrib- uted to the increasing temperature in the region, especially from the late 1980s - HISTALP data set (Auer et al., 2007). The potential effect of parameters as temperature should also explain the differences between eutrophication and re-oligotrophication trajectories

\section{CONCLUSIONS}

Paleolimnological methods using diatoms can suffer from some bias due to, for example, valve preservation in the sediment, especially for thinly silicified species, or to the presence of benthic species in sediment in very deep part of lakes (Battarbee et al., 2002). However, the comparison of limnological and palaeolimnological datasets for lake Geneva confirmed the faithfulness of the palaeolimnological records for these sub-Alpine lakes. The fossil diatom records are, therefore, appropriate for assessing environmental change in these systems. The comparison between DI-TP and limnological monitoring data showed good agreement, thus enabling the reconstruction trophic history of the three study lakes and the establishment of relatively accurate reference $\mathrm{P}$ concentrations. However, in spite of the bias inherent to the used transfer function models [like WA, which assume, for example, always an unimodal relationship between species and environmental variables even if some taxa may show a skewed unimodal or sigmoid (and not linear) response (Birks 1998; Huisman et al., 1993)], transfer functions have been used in the past to infer different limnological variables. One important point in the application of transfer functions is that the inferred variable should be an important factor controlling the development of the specific community used for inference. In the case of diatoms, it is well known that species distribution is mainly dependent on salinity, $\mathrm{pH}$, trophic status and habitat availability.

Part of the diatom responses observed during re-oligotrophication might also be driven by climate variability. Climate change and the lakes responses to the combination of decreasing TP concentration and climate change are still difficult to understand (Battarbee et al., 2005). Perspectives to this work would be to quantify the role of the different perturbations that potentially impacted the diatom communities in these three lakes changing their compositions (eutrophication, climate change and fisheries management practices). This kind of study has been already done for Esthwaite Water (Dong et al., 2011). Such an approach is required to evaluate how much the diatom composition at the TP restoration objectives might differ from those observed at temporal reference conditions.

\section{ACKNOWLEDGMENTS}

This study has been supported by the French National Research Agency (ANR-VUL 005: IPER-RETRO project). CIPEL, CISALB and SILA have also to be acknowl- 
edged for their cooperation in the monitoring. J.C. Druart is thanked for his work for diatom and phytoplankton determinations and Benjamin Alric, for having brought data on Cladocerans fossil records. Lastly, we are grateful to the reviewers for their valuable comments.

\section{REFERENCES}

AFNOR, 2004. Water quality - Guidance standard for the identification, enumeration and interpretation of benthic diatom samples from rivers and lakes. Association Française de Normalisation: $13 \mathrm{pp}$.

AFNOR, 2006. EN 15204 - Water quality - Guidance standard on the enumeration of phytoplankton using inverted microscopy (Utermöhl technique). Association Française de Normalisation: 39 pp.

Alric B, 2012. Local forcings affect the vulnerability and responses of lake pelagic food webs to climate change: A paleo-ecological approach based on cladoceran. $\mathrm{PhD}$ Thesis, University of Grenoble.

Alric B, Perga ME, 2011. Effects of production, sedimentation and taphonomic processes on the composition and size structure of sedimenting cladoceran remains in a large deep sub-Alpine lake: paleo-ecological implications. Hydrobiologia 676:101-116.

Anneville O, 2002. Long-term study (1974-1998) of seasonal changes in the phytoplankton in Lake Geneva: a multi-table approach. J. Plankton. Res. 24:993-1008.

Auer I, Böhm R, Jurkovic A, Lipa W, Orlik A, Potzmann R, Schöner W, Ungersböck M, Matulla C, Briffa K, Jones P, Efthymiadis D, Brunetti M, Nanni T, Maugeri M, Mercalli L, Mestre O, Moisselin JM, Begert M, Müller-Westermeier G, Kveton V, Bochnicek O, Stastny P, Lapin M, Szalai S, Szentimrey T, Cegnar T, Dolinar M, Gajic-Capka M, Zaninovic K, Majstorovic Z, Nieplova E, 2007. HISTALP-historical instrumental climatological surface time series of the Greater Alpine Region. Int. J. Climatol. 27:17-46.

Battarbee R, Anderson NJ, Jeppesen E, Leavitt PR, 2005. Combining palaeolimnological and limnological approaches in assessing lake ecosystem response to nutrient reduction. Freshwater Biol. 50:1772-1780.

Battarbee R, Jones V, Flower R, Cameron N, Bennion H, Carvalho L, Juggins S, 2002. Diatoms, p. 155-202. In: J. Smol, H. J. Birks, W. Last, R. Bradley and K. Alverson (eds.), Tracking environmental change using lake sediments. Springer, The Netherlands.

Bennett K, 2006. Determination of the number of zones in a biostratigraphical sequence. New Phytol. 132:155-170.

Bennion H, Battarbee RW, 2007. The European Union water framework directive: opportunities for palaeolimnology. J. Paleolimnol. 38:285-295.

Bennion H, Johnes P, Ferrier R, Phillips G, Haworth E, 2005. A comparison of diatom phosphorus transfer functions and export coefficient models as tools for reconstructing lake nutrient histories. Freshwater Biol. 50:1651-1670.

Bennion H, Wunsam S, Schmidt R, 1995. The validation of diatom-phosphorus transfer functions: an example from Mondsee, Austria. Freshwater Biol. 34:271-283.

Berthon V, Bouchez A, Rimet F, 2011. Using diatom life-forms and ecological guilds to assess organic pollution and trophic level in rivers: a case study of rivers in south-eastern France. Hydrobiologia 673:259-271.

Birks H, 1998. Numerical tools in palaeolimnology. Progress, potentialities, and problems. J. Paleolimnol. 20: 307-332.

Birks H, Line J, Juggins S, Stevenson AC, ter Braak CJF, 1990. Diatoms and $\mathrm{pH}$ reconstruction. Philos. T. R. Soc. Lon. B 327:263-278.

Blais JM, Kalff J, 1995. The influence of lake morphometry on sediment focusing. Limnol. Oceanogr. 40:582-588.

De Caceres M, Oliva F, Font X, Vives S, 2007. Ginkgo, a program for non-standard multivariate fuzzy analysis. Adv. Fuzzy Sets Syst. 2:41-56.

DeMott W, Gulati R, 1999. Phosphorus limitation in Daphnia: evidence from a long term study of three hypereutrophic Dutch lakes. Limnol. Oceanogr. 44:1557-1564.

Dong X, Bennion H, Maberly S, Sayer C, Simpson GL, Battarbee RW, 2011. Nutrients exert a stronger control than climate on recent diatom communities in Esthwaite Water: evidence from monitoring and palaeolimnological records. Freshwater Biol. 57:2044-2056.

Druart J.-C. and Pelletier J. 1998. Variation of the trophic status of Lake Annecy (Haute-Savoie, France) estimated from the diatoms and algal pigment composition in cores. Arch. Sci. 51: 325-333.

Dufrene M. and Legendre P. 1997. Species assemblages and indicator species: The need for a flexible asymmetrical approach. Ecol. Monogr. 67: 345-366.

European Commission, 2000. Directive 2000/60/EC of the European Parliament and of the Council of 23 October 2000 Establishing a Framework for Community Action in the Field of Water Policy. Official Journal L327:1-72.

European Commission, 2003. Common Implementation Strategy for the Water Framework Directive (2000/60/EC). River and lakes - Typology, reference conditions and classification systems. Guidance document no. 10. Available from: http://www.waterframeworkdirective.wdd.moa.gov.cy/docs/ GuidanceDocuments/Guidancedoc10REFCOND.pdf

Flower R, 1993. Diatom preservation: experiments and observations on dissolution and breakage in modern and fossil material. Hydrobiologia 269/270:473-484.

Giguet-Covex C, Arnaud F, Poulenard J, Enters D, Reyss JL, Millet L, Lazzarotto J, Vidal O, 2010. Sedimentological and geochemical records of past trophic state and hypolimnetic anoxia in large, hard-water Lake Bourget, French Alps. J. Paleolimnol. 43:171-190.

Houk V, Klee R, Tanaka H, 2010. Atlas of freshwater centric diatoms with a brief key and descriptions. Part III, Stephanodiscaceae A, Cyclotella, Tertiarius, Discotella. Fottea 10:1-498.

Huisman J, Olff H, Fresco L, 1993. A hierarchical set of models for species response analysis. J. Vegetation Sci. 4:37-46.

Jacquet S, Briand JF, Leboulanger C, Avois-Jacquet C, Oberhaus L, Tassin B, Vinçon-Leite B, Paolini G, Druart JC, Anneville O, Humbert JF, 2005. The proliferation of the toxic cyanobacterium Planktothrix rubescens following restoration of the largest natural French lake (Lac du Bourget). Harmful Algae 4:651-672.

Jenny JP, Arnaud F, Dorioz JM, Giguet Covex C, Frossard V, Sabatier P, Millet L, Reyss JL, Tachikawa K, Bard E, Pignol C, Soufi F, Romeyer O, Perga M, (2013). A spatiotemporal 
investigation of varved sediments highlights the dynamics of hypolimnetic hypoxia in a large hard-water lake over the last 150 years. Limnol. Oceanogr. (in press).

Juggins S, 2007. C2 Version 1.5 User guide. Software for ecological and palaeoecological data analysis and visualisation. Newcastle University, Newcastle-upon-Tyne.

Juggins S, 2009. Package 'rioja'. R package for analysis of Quaternary Science data. Available from: http://cran.uvigo.es/ web/packages/rioja/rioja.pdf

Juggins S, Anderson NJ, Hobbs JR, Heathcote A, 2013. Reconstructing epilimnetic total phosphorus using diatoms: statistical and ecological constraints. J. Paleolimnol. 49: 373-390.

Krammer K, Lange-Bertalot H, 1986. [Bacillariophyceae, 1. Teil: Naviculaceae]. [Book in German]. Gustav Fischer Verlag: 876 pp.

Krammer K, Lange-Bertalot H, 1988. [Bacillariophyceae 2. Teil: Bacillariaceae, Epithemiaceae, Surirellaceae]. [Book in German]. Gustav Fischer Verlag: 596 pp.

Krammer K, Lange-Bertalot H, 1991a. [Bacillariophyceae 3. Teil: Centrales, Fragilariaceae, Eunotiaceae]. [Book in German]. Gustav Fischer Verlag: 576 pp.

Krammer K, Lange-Bertalot H, 1991b. [Bacillariophyceae 4. Teil: Achnanthaceae. Kritische Ergänzungen zu Navicula (Lineolatae) und Gomphonema]. [Book in German]. Gustav Fischer Verlag: 437 pp.

Lazzarotto J, Nirel P, Rapin F, 2011. [Physical-chemical changes in the waters of Lake Geneva (major-elements)], p. 31-63. In: CIPEL (ed.), [Rapp. Comm. int. prot. eaux Léman contre pollut.]. [Book in French], Campagne 2010, Lausanne.

Likens GE, Davis MB, 1975. Post-glacial history of Mirror Lake and its watershed in New Hampshire, USA: An initial report. Int. Ver. Theor. Angew. 19:982-993.

Loga M, Hollan E, Lemmin U, Baumert H, Guilbaud C, Frisk T, Fontvieille D, Wahl B, Güde H, May L, Carvalho L, Duwe K. 2004. Key processes. EUROLAKES D38. Report to European Union, Brussels: 91 pp.

Mantel N, 1967. The detection of disease clustering and a generalized regression approach. Cancer Res. 27:209-220.

Marchetto A, Bettinetti R, 1995. Reconstruction of the phosphorus history of two deep, sub-Alpine Italian lakes from sedimentary diatoms, compared with long-term chemical measurements. Mem. Ist. Ital. Idrobiol. 53:27-38.

Marchetto A, Lami A, Musazzi S, Massaferro J, Langone L, Guilizzoni P, 2004. Lake Maggiore (N. Italy) trophic history: fossil diatom, plant pigments, and chironomids, and comparison with long-term limnological data. Quatern. Int. 113:97-110.

Marchetto A, Musazzi S, 2001. Comparison between sedimentary and living diatoms in Lago Maggiore (N. Italy): implications of using transfer functions. J. Limnol. 60:19-26.

McCune B, Mefford MJ, 2006. PC-ORD. Multivariate Analysis of Ecological Data. Version 5. MjM Software, Gleneden Beach, USA: 24 pp.

Millet L, Giguet-Covex C, Verneaux V, Druart J, Adatte T, Arnaud F, 2010. Reconstruction of the recent history of a large deep prealpine lake (Lake Bourget, France) using subfossil chironomids, diatoms, and organic matter analysis: towards the definition of a lake-specific reference state. J. Paleolimnol. 44:963-978.

Overpeck JT, Webb III T, Prentice IC, 1985. Quantitative inter- pretation of fossil pollen spectra: Dissimilarity coefficients and the method of modern analogs. Quaternary Res. 23:87108.

Perga ME, Desmet M, Enters D, Reyss J, 2010. A century of bottom-up-and top-down-driven changes on a lake planktonic food web: a paleoecological and paleoisotopic study of Lake Annecy, France. Limnol. Oceanogr. 55:803-816.

Prygiel J, Carpentier P, Almeida S, Coste M, Druart JC, Ector L, Guillard D, Honoré MA, Iserentant R, Ledeganck P, Lalanne-Cassou C, Lesniak C, Mercier I, Moncaut P, Nazart M, Nouchet N, Peres F, Peeters V, Rimet F, Rumeau A, Sabater S, Straub F, Torrisi M, Tudesque L, Van de Vijver B, Vidal H, Vizinet J, Zydek N, 2002. Determination of the biological diatom index (IBD NF T 90-354): results of an intercomparison exercise. J. Appl. Phycol. 14:27-39.

Rapin F, Blanc P, Corvi C, 1989. [Influence des apports sur le stock de phosphore dans le lac Léman et sur son eutrophisation]. [Article inFrench]. J. Water Sci. 2:721-737.

Renberg I, 1990. A procedure for preparing large sets of diatom slides from sediment cores. J. Paleolimnol. 4:87-90.

Rimet F, Bouchez A, 2012a. Biomonitoring river diatoms: implications of taxonomic resolution. Ecol. Indic. 15:92-99.

Rimet F, Bouchez A, 2012b. Life-forms, cell-sizes and ecological guilds of diatoms in European rivers. Knowl. Manag. Aquat. Ec. 406:01.

Rimet F, Druart J, Anneville O, 2009. Exploring the dynamics of plankton diatom communities in Lake Geneva using emergent self-organizing maps (1974-2007). Ecol. Inform. 4:99-110.

Telford R, Birks HJB, 2009. Evaluation of transfer functions in spatially structured environments. Quaternary Sci. Rev. 28:1309-1316.

Ter Braak CJF, Juggins S, 1993. Weighted averaging partial least squares regression (WA-PLS): an improved method for reconstructing environmental variables from species assemblages. Hydrobiologia 269/270:485-502.

Ter Braak CJF, Van Dam H, 1989. Inferring pH from diatoms: a comparison of old and new calibration methods. Hydrobiologia 178:209-223.

Utermohl H, 1958. [Zür Vervollkommung der quantitative Phytoplankton Methodik]. [Article in German]. Int. Ver. Theor. Angew. 9:1-38.

Wessels M, Mohaupt K, Kümmerlin R, Lenhard A, 1999. Reconstructing past eutrophication trends from diatoms and biogenic silica in the sediment and the pelagic zone of Lake Constance, Germany. J. Paleolimnol. 21:171-192.

Wolfram G, Argillier C, Bortoli J, Buzzi F, Dalmiglio A, Dokulil M, Hoehn E, Marchetto A, Martinez PJ, Morabito G, Reichmann M, Remec-Rekar Š, Riedmüller U, Rioury C, Schaumburg J, Schulz L, Urbanič G, 2009. Reference conditions and WFD compliant class boundaries for phytoplankton biomass and chlorophyll-a in Alpine lakes. Hydrobiologia 633:45-58.

Wunsam S, Schmidt R, 1995. A diatom-phosphorus transfer function for Alpine and pre-Alpine lakes. Mem. Ist. Ital. Idrobiol. 53:85-99.

Zolitschka B, 2003. Dating based on freshwater- and marinelaminated sediments, p. 92-106. In: A. Mackay, R.W. Battarbee, J. Birks and F. Oldfield (eds.), Global change in the Holocene. Edward Arnold Publ., London. 